\title{
Thoracic aortic dissection - typical and atypical symptoms
}

\section{Vedrana Baraban"*, Joško Bulum², Hrvoje Roguljić', Dražen Mlinarević', Livija Sušić ${ }^{3,4}$, Zorin Makarović'}

IJ. J. Strossmayer University of Osijek Faculty of Medicine, University Hospital Centre Osijek, Osijek, Croatia

2University of Zagreb School of Medicine, University Hospital Centre Zagreb, Zagreb, Croatia

${ }^{3}$ Health Centre Osijek, Osijek, Croatia

${ }^{4}$ J.J.Strossmayer University of Osijek Faculty of Medicine, Osijek, Croatia

RECEIVED:

September 24, 2017

ACCEPTED:

September 26, 2017

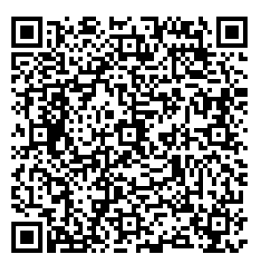

KEYWORDS: chest pain, aortic dissection, interventional cardiology.

CITATION: Cardiol Croat. 2017;12(9-10):386. I https://doi.org/10.15836/ccar2017.386

*ADDRESS FOR CORRESPONDENCE: Vedrana Baraban, Klinički bolnički centar Osijek, Josipa Huttlera 4, HR-31000 Osijek, Croatia. / Phone: 385-91-200-2171 / E-mail: vbaraban@gmail.com

ORCID: Vedrana Baraban http://orcid.org/0000-0002-9724-0785 • Joško Bulum http://orcid.org/0000-0002-1482-6503 Hrvoje Roguljić http://orcid.org/0000-0002-3747-9305 • Dražen Mlinarević http://orcid.org/0000-0003-3246-4056 Livija Sušić http://orcid.org/0000-0001-7271-4449 • Zorin Makarović http://orcid.org/0000-0002-6689-3177

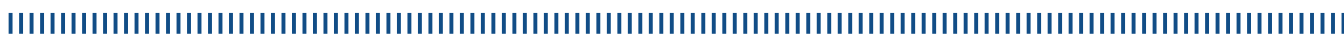

Introduction: Acute aortic dissection is a life-threatening condition characterized with separation of the layers within the aortic wall. It is associated with high morbidity and mortality rates in spite of prompt medical treatment ${ }^{1}$.

Case report: 44-year-old man was admitted to the Coronary Care Unit from the Emergency Department with a diagnosis of acute myocardial infarction with ST elevation in precordial leads. The only chronic disease in his medical history was hypertension for which he was treated for the last three years. Due to the chest pain with ECG changes suggesting acute coronary syndrome and initially elevated troponin level (troponin I $0.165 \mathrm{ug} / \mathrm{L}$ ) an urgent coronary angiography was performed. The angiogram showed no significant lesions of epicardial arteries. Due to the ongoing chest pain, persistent high blood pressure and elevated D-dimer levels (2.818 ug/L), a CT angiography of aorta was performed. CT angiogram revealed an acute Stanford type B dissection of the descending aorta. Due to the unavailability of endovascular treatment options in our hospital, the patient was immediately transferred to University Hospital Centre (UHC) Zagreb for thoracic endovascular aortic repair procedure which was successfully performed. During further hospitalization in UHC Zagreb the patient developed posterior reversible encephalopathy syndrome due to extremely high blood pressure levels.

Conclusion: Aortic dissection has to always be included in the differential diagnosis of acute chest pain when it is associated with high blood pressure and elevated levels of D-dimer, especially when the patient has low serial troponin levels and a normal coronary angiogram. Interestingly, our patient had chest pain without propagation to any extremity or the to the neck and palpable, symmetrical arterial pulsations on all extremities. Therefore we conclude that atypical clinical presentation should not distract from making a correct diagnosis of acute aortic dissection.

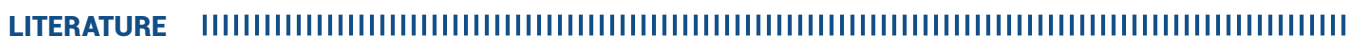

1. Erbel R, Aboyans V, Boileau C, Bossone E, Bartolomeo RD, Eggebrecht H, et al; ESC Committee for Practice Guidelines. 2014 ESC Guidelines on the diagnosis and treatment of aortic diseases: Document covering acute and chronic aortic diseases of the thoracic and abdominal aorta of the adult. The Task Force for the Diagnosis and Treatment of Aortic Diseases of the European Society of Cardiology (ESC). Eur Heart J. 2014 Nov 1;35(41):2873-926. https://doi.org/10.1093/eurheartj/ehu281 